\title{
MAKNA KASIH DALAM KOMPOSISI “UNA LIMOSNA POR EL AMOR DE DIOS" KARYA AGUSIN BARRIOS MANGORE
}

\author{
${ }^{1}$ Recky Rusman, ${ }^{2}$ Meyltsan Herbert Maragani \\ ${ }^{1}$ Mahasiswa Pendidikan Musik Gereja IAKN Manado, ${ }^{2}$ Dosen Pendidikan Musik Gereja \\ IAKN Manado \\ 2ilzanmaragani@iakn-manado.ac.id
}

\begin{abstract}
Abstrak
Penelitian ini bertujuan untuk mendeskripsikan makna kasih dalam komposisi "Una Limosnita Por El Amor de Dios" karya Agustin Barrios Mangore. Metode yang digunakan dalam penelitian ini adalah metode kualitatif dengan pendekatan deskriptif kualitatif. Berdasarkan hasil analisis dan interpretasi data, diperoleh indikasi bahwa makna kasih dari komposisi "Una Limosnita Por El Amor de Dios" tercermin pada judul dan unsur-unsur musikal dalam komposisi tersebut. Judul lagu yang berarti "Sedekah Tuan demi Kasih Tuhan" memiliki makna hidup saling mengasihi sesama (kasih Philia) untuk mencerminkan kasih Tuhan (kasih Agape). Unsur-unsur yang mendukung penyampaian makna dalam komposisi lagu Una Limosnita Por El Amor de Dios ialah penggunaan tangga nada minor dan modulasi ke tangga nada mayor, interval melodi yang melangkah, ornamen Tremolo disepanjang lagu, intro yang menjadi motif iringan di sepanjang lagu, adanya akur Picardy di akhir pengulangan tema, penggunaan akur diminished sebelum akur mayor di akhir lagu, dinamika yang dimainkan berdasarkan perasaan dari pemain.
\end{abstract}

Kata Kunci: Makna Kasih, Komposisi, Una Limosnita Por El Amor de Dios, Agustin Barrios Mangore.

\section{THE MEANING OF LOVE IN THE COMPOSITION OF "UNA LIMOSNA POR EL AMOR DE DIOS" WORKS AGUSIN BARRIOS MANGORE}

\begin{abstract}
This research aims to describe the meaning of love in the composition "Una Limosnita Por El Amor de Dios" by Agustin Barrios Mangore. The method used in this research is a qualitative method with a qualitative descriptive approach. Based on the results of the analysis and interpretation of the data, an indication that the meaning of love from the composition "Una Limosnita Por El Amor de Dios" is reflected in the title and musical elements in the composition. The title of the song, which means "Charity for the Love of God" has the meaning of living in loving one another (Philia's love) to reflect God's love (Agape love). The elements that support the delivery of meaning in the composition of the song Una Limosnita Por El Amor de Dios are the use of minor scales and modulation to major notes, stepping melody intervals, tremolo ornaments throughout the song, intros which are accompaniment motifs along the song, there are along Picardy at the end of the repetition of the theme, the use of the plot is diminished before the major line at the end of the song, the dynamics that are played are based on the feelings of the player.
\end{abstract}

Keywords: The Meaning of Love, Composition, Una Limosnita Por El Amor de Dios, Agustin Barrios Mangore

\section{Pendahuluan}

Musik pada hakikatnya adalah bagian dari seni yang menggunakan bunyi sebagai media penciptaannya. Terdapat berbagai macam definisi tentang musik yang dikemukakan oleh para ahli namum belum 
dapat mendefinisikan musik secara komprehensif. Beberapa definisi menjelaskan musik sebagai kesan terhadap sesuatu yang ditangkap oleh indera pendengarannya, namun terdapat juga pemahaman bahwa musik adalah suatu karya seni dengan segenap unsur pokok dan pendukungnya. Jamalus mendefinisikan musik adalah suatu hasil karya seni bunyi dalam bentuk lagu atau komposisi musik yang mengungkapkan pikiran dan perasaan penciptanya melalui unsur-unsur musik yaitu irama, melodi, harmoni, bentuk dan struktur lagu dan ekspresi sebagai satu kesatuan. ${ }^{1}$ sejalan dengan pemahaman tersebut, Prier menyatakan persamaan pendapat yang dikemukakan oleh Aristoteles bahwa musik merupakan curahan kekuatan tenaga penggambaran yang berasal dari gerakan rasa dalam suatu rentetan suara (melodi) yang berirama. ${ }^{2}$ Berdasarkan pemahaman terebut, dapat dikatakan bahwa musik merupakan suatu ungkapan ide/gagasan atau penggambaran terhadap sesuatu, yang dituangkan melalui unsur-unsur musik yaitu ritme, melodi, harmoni dan dinamika menjadi satu kesatuan yang utuh.

Musik dalam pengelompokkannya dibagi dalam 3 bagian besar, yaitu musik vokal, instrumen, dan gabungan antara keduanya. Musik vokal merupakan musik yang dihasilkan dari manusia, sedangkan

1 Jamalus, Pengajaran Musik Melalui Pengalaman Musik, (Jakarta: Depdikbud Ditjen Dikti. Proyek Pengembangan LPTK, 1988), H. 1 ${ }^{2}$ Karl-Edmund Prier, IImu Bentuk Musik, (Yogyakarta: Pusat Musik Liturgi, 1996), H. 9 musik instrumental merupakan komposisi musik tanpa syair dalam bentuk instrumen apapun, dan yang terakhir musik gabungan antara vokal dan instrumen. Membahas mengenai musik instrumental, dibutuhkan pengetahuan mendalam mengenai kondisi jaman pada saat musik itu diciptakan, karena di dalamnya tidak mengandung unsur bahasa secara verbal, hanya rangkaian nada dan harmoni dari satu atau lebih alat musik.

Salah satu instrumen yang digunakan untuk mengekspresikan musik adalah gitar. Gitar merupakan salah satu alat musik dalam kategori chordophone dan mempunyai karakteristik tersendiri baik dari segi bentuk maupun suara yang dihasilkan. Dari sekian banyak jenis gitar, gitar klasik merupakan salah satu instrumen yang digunakan untuk membawakan karya-karya solo dari era klasik sampai modern. Dari sekian banyak komposer di era romantik, terdapat salah satu komposer yang memiliki produktivitas dan melakukan pembaharuanpembaharuan dari segi teknik maupun lagu, yaitu Agustin Barrios Mangore (1885-1944). Barrios merupakan komposer sekaligus pemain gitar berkebangsaan Paraguay. Musik Barrios banyak mencerminkan aspek kehidupan yang sangat mencintai tanah airnya. Barrios sangat mengapresiasi musik Bach dan banyak mentranskrip musik Bach untuk komposisi gitar sehingga membantu dalam pemahaman yang jauh lebih baik dalam harmoninya.

Karya Barrios terdiri dari bermacam gaya, yaitu: barok, klasik dan romantik di 
mana ia membuat prelude, studies atau etude, waltz, marzukas, tarantellas, romansa dan juga beberapa karya yang mencerminkan tentang sebuah objek ataupun karya yang bertemakan kisahkisah kebudayaan dan kehidupan yang religious. Salah satu lagu yang bertemakan kehidupan religiusnya adalah Una Limosnita Por El Amor de Dios.

Lagu Una Limosnita Por El Amor de Dios memiliki latar belakang yang sangat menginspirasi. Pada saat itu, Barrios menghabiskan tahun-tahun terakhir kehidupannya di kota San Salvador, El Savador bersama rekan dan muridmuridnya. Pada suatu sore, ketika selesai mengajar, pintu rumahnya diketuk oleh seorang pengemis tua yang meminta sedekah kepadanya. Pengemis itu berkata: "Una limosnita por el amor de Dios". Mangore yang iba kepada pengemis tua itu kemudian memberikan uang kepadanya. la merasa perlu membantu sesama untuk mencerminkan kasih Tuhan, apalagi saat itu ia merasa bahwa hidupnya sudah tidak akan lama lagi. ${ }^{3}$ Kata-kata dari pengemis tua itu kemudian menginspirasinya untuk membuat lagu Una Limosnita Por El Amor de Dios.

Kata makna pada dasarnya digunakan dalam berbagai bidang maupun konteks pembicaraan. Pengertian khusus kata makna tersebut serta perbedaannya dengan ide misalnya, tidak begitu

${ }^{3}$ Maurice J. Summerfield. The Classical Guitar: Its Evolution, Players and Personalities since 1800. (London: Ashley Mark Publishing. 1991). H. 67 diperhatikan. Oleh sebab itu, sudah sewajarnya bila makna juga dijajarkan pengertiannya dengan arti. Berbagai pengertian itu begitu saja disejajarkan dengan kata makna karena keberadaannya memang tidak pernah dikenali secara cermat dan dipilahkan secara tepat. Kata makna sebagian istilah mengacu pada pengertian yang sangat luas. Adapun batasannya adalah makna sebagai hubungan antara bahasa dengan dunia luar yang telah disepakati bersama oleh pemakai bahasa sehingga dapat saling dimengerti. ${ }^{4}$

Dari gagasan batasan pengertian tersebut itu dapat diketahui adanya tiga unsur produk yang tercangkup di dalamnya yakni, makna adalah hubungan antara bahasa dengan dunia luar, penentuan hubungan terjadi karena kesepakatan para pemakai, perwujudan makna itu dapat digunakan untuk menyampaikan informasi sehingga dapat saling dimengerti.

Gambaran tentang kasih diberikan oleh Allah yang telah memberikan anak-Nya yang tunggal untuk menebus dosa manusia. Hal ini membuat kasih itu menjadi hal yang nyata bukan hanya ucapan saja. Sebagai subjek yang telah menerima kasih Allah, sudah sewajibnya kita memelihara kasih itu dalam kehidupan kita sehari-hari. Di dalam Alkitab sendiri definisi dari kasih terdapat dalam Surat 1 Korintus 13: 47,yang berbunyi:

\footnotetext{
4 John Fiske, Cultural and Communications Studies, (Yogyakarta: Jalasutra, 2004), H.
} 
"Kasih itu sabar; kasih itu murah hati; ia tidak cemburu. la tidak memegahkan diri dan tidak sombong. la tidak melakukan yang tidak sopan dan tidak mencari keuntungan diri sendiri. la tidak pemarah dan tidak menyimpan kesalahan orang lain. la tidak bersukacita karena ketidakadilan, tetapi ia bersukacita karena kebenaran. la menutupi segala sesuatu, percaya segala sesuatu, mengharapkan segala sesuatu, sabar menanggung segala sesuatu."

Dalam Perjanjian Lama, kata yang paling dominan untuk kasih adalah "aheb", berkonotasi beragam makna sesuai dengan konteksnya. Sedangkan dalam Perjanjian Baru kebanyakan menggunakan dua kata Yunani: "agape" dan " philia". Kata "agape" adalah kata yang paling dominan dalam Perjanjian Baru. Kata "agape" jarang digunakan dalam bahasa Yunani sebelum kata itu dipakai secara khas oleh orang Kristen untuk mengungkapkan kasih. $^{5}$ "Agape" dipakai untuk menyatakan kasih Allah, kasih sejati, tidak mementingkan diri sendiri, tidak menuntut balas jasa, dan kasih dari hati yang peduli kepada orang lain. Sedangkan kata "philia", yaitu kasih sayang antara sahabat atau teman; kasih ini sering diasosiasikan dengan kasih persaudaraan. Dua kata Yunani klasik "eros" dan "storge" tidak digunakan dalam

${ }^{5} \mathrm{http}: / /$ artikel.sabda.org/kasih_kristiani_mengakt ualisasi_kasih_yang_tergambar_dalam_ 1_korintus_13
Alkitab. Kata "eros", menunjukkan cinta dengan daya tarik seksual atau erotika. Kasih ini sering dihubungkan dengan romantistik. Sedangkan kata "storge" berarti kasih alami dalam keluarga, seperti kasih seorang ibu dan anaknya tidak digunakan di dalam Alkitab. ${ }^{6}$ Kasih "agape" dapat diaktualisasikan kepada Allah dan kepada sesama. Secara khusus, dalam konteks 1 Korintus 13, Paulus menggunakan kata "agape" dalam hubungan dengan sesama. Kristus dalam Matius 22:34-40 meringkas tugas orang Kristen dengan hukum kasih,yaitu kasih kepada Tuhan dan kepada sesama. Kasih "agape" perlu memenuhi hidup kita dan mengontrol kasih yang lainnya (philia, eros, storge).29 Semua kasih yang lain hanya dapat diperbaiki dan berfungsi dengan benar dalam proporsi yang tepat bila kasih "agape" mengontrolnya. Kasih ini mengatur relasi kita dalam keluarga, sesama, di tempat kerja (Yoh 13:34), dan bagi mereka yang membutuhkan bahkan mereka yang memusuhi (Luk 10: 25-37).

\section{Metode}

Metode yang digunakan dalam penelitian ini adalah kualitatif dengan menggunakan pendekatan deskriptif kualitatif untuk menganalisis bentuk musik dan makna kasih dalam komposisi Una Limosnita Por El Amor de Dios" karya Agustin Barrios Mangore. Teknik pengumpulan data dalam penelitian ini ${ }^{6} \mathrm{Ibid}$ 
dilakukan dengan metode studi pustaka. Studi pustaka adalah teknik menggali data dengan melakukan penelaahan terhadap berbagai buku, literatur, catatan, dan berbagai pelaporan yang membahas dengan masalah yang ingin dipecahkan.

\section{Hasil dan Pembahasan}

\section{Makna Kasih dalam Komposisi Lagu}

“Una Limosnita Por El Amor de Dios"

Makna kasih yang terdapat dalam komposisi lagu ini, yang pertama dapat dilihat dari judul, yaitu "Una Limosnita Por El Amor de Dios" yang berarti "Sedekah tuan demi kasih Tuhan". Kata "Por El Amor de Dios"yang berarti "demi kasih Tuhan" digunakan oleh pengemis itu dengan maksud untuk mengingatkan kembali akan kasih Tuhan. Kata "kasih" disini lebih cenderung menggambarkan kasih "Philia" yang dikontrol oleh kasih "agape". Implementasi dari kasih "Philia" atau kasih persaudaraan salah satunya adalah dengan memperhatikan sesama (memberi sedekah kepada sesama). Seperti juga cerita tentang orang Samaria yang memperhatikan sesamanya yang tertulis dalam Injil Lukas 10:25-37. Selain dari judul, makna kasih juga dapat dilihat dari unsur-unsur yang terkandung dalam komposisi lagu Una Limosnita Por El Amor de Dios.

Pertama dari tangga nada. Penggunaan tangga nada minor yang menggambarkan suasana sedih, sentimentil dan melankolik. ${ }^{7}$ Penciptaan suasana yang sentimentil bertujuan untuk menggugah perasaan para pendengar agar dapat merasakan maksud dan ide yang terkandung dalam komposisi lagu. Ide yang hendak digambarkan oleh komposer ialah permohonan dari pengemis tua untuk mendapatkan sedekah. Ide ini dapat dilihat dengan jelas melalui melodi lagu dari birama 3-4. Adanya penurunan nada dari nada ë ke nada ġ menggunakan teknik Glisando menggambarkan seperti rintihan atau permohonan. Kemudian terjadi modulasi ke tangga nada mayor. Tangga nada mayor menggambarkan suasana yang tenang dan damai. Maksud dari penggunaan tangga nada mayor ini adalah memunculkan harapan yang dapat dirasakan dari perpindahan tangga nada minor ke tangga nada mayor. Pada akhir dari lagu, komposer menggunakan akur diminished dan ditutup oleh akur mayor menggambarkan bahwa permohonan dan harapan dari pengemis itu telah terwujud.

Kedua, Intro pada birama 1-2 merupakan gambaran dari ketukan pintu sang pengemis tua. ${ }^{8}$ Ketukan ini hadir terus di sepanjang lagu menggambarkan suasana haru untuk mengetuk pintu hati tuan rumah sehingga tuan rumah mau mengulurkan tangan dan membantu sebagai perpanjangan tangan Tuhan kepada pengemis tua itu. Komposer

${ }^{7}$ https://thehub.musiciansfriend.com/techtips/whats-the-difference-between-majorandminor-chords

${ }^{8}$ Jesus Banitez R. A. Barrios Mangore No. 2. H. 47 
membuat intro lagu ini menjadi iringan di sepanjang lagu untuk menyampaikan pesan kasih bahwa setiap hari Tuhan mengetuk pintu hati kita untuk dapat berbuat baik kepada sesama yang membutuhkan, karena orang-orang susah setiap hari ada di sekitar kita.

Ketiga ialah tema. Terjadi pengulangan tema pada birama 19-26. Pada pengulangan tema ini diakhiri dengan akur mayor, atau disebut juga picardy. Penggunaan akur mayor pada akhir tema ini menggambarkan pengharapan yang muncul setelah suasana haru yang terjadi dari awal lagu.

Keempat ialah ornament. Komposer menggunakan ornamen tremolo hampir di sepanjang lagu untuk memunculkan efek kelembutan dan suasana permohonan. Efek kelembutan berfungsi untuk mendukung penyampaian ide komposer atau pemain gitar kepada pendengar. Komposisi "Una Limosnita Por El Amor de Dios" karya Agustin Barrios Mangore ini mengingatkan kembali bahwa kita harus memiliki kasih dan hidup saling mengasihi.

Seperti juga yang diajarkan dalam Alkitab, bahwa hidup tanpa kasih adalah sia-sia, 1 Kor 13: 1-2 ;

"Sekalipun aku dapat berkata-kata dengan semua bahasa manusia dan bahasa malaikat, tetapi jika aku tidak mempunyai kasih, aku sama dengan gong yang berkumandang dan canang yang bergemerincing. Sekalipun aku mempunyai karunia untuk bernubuat dan aku mengetahui segala rahasia dan memiliki seluruh pengetahuan; dan sekalipun aku memiliki iman yang sempurna untuk memindahkan gunung, tetapi jika aku tidak mempunyai kasih, aku sama sekali tidak berguna."

Karena kehidupan manusia lebih cenderung memikirkan kepentingan diri sendiri daripada kepentingan bersama. Hal itu dapat kita lihat dalam kehidupan seharihari, baik diluar kekristenan maupun orang Kristen itu sendiri. Seberapa luas pengetahuan kita tentang teologia tetapi jika kita tidak memiliki kasih, tidak akan menjadi berkat bagi orang lain, sebab implementasi dari kasih bukan hanya melalui kata-kata melainkan lebih kepada perbuatan. Begitu juga halnya dalam dunia musik. Bukan hanya lagu yang mempunyai lirik yang dapat menyampaikan makna kasih, tetapi lewat sentuhan melodi lagu tanpa lirik juga mampu menyampaikan makna kasih.

\section{Kesimpulan}

Komposisi lagu Una Limosnita Por El Amor de Dios mencerminkan makna kasih dari judul dan unsur-unsur musiknya. Judul lagu yang berarti "Sedekah Tuan demi Kasih Tuhan" memiliki makna hidup saling mengasihi sesama (kasih Philia) untuk mencerminkan kasih Tuhan (kasih Agape). Unsur-unsur yang mendukung penyampaian makna dalam komposisi lagu 
Una Limosnita Por El Amor de Dios ialah penggunaan tangga nada minor dan modulasi ke tangga nada mayor, interval melodi yang melangkah, ornament Tremolo disepanjang lagu, intro yang menjadi motif iringan di sepanjang lagu, adanya akur Picardy di akhir pengulangan tema, penggunaan akur diminished sebelum akur mayor di akhir lagu, dan dinamika yang dimainkan berdasarkan perasaan dari pemain.

\section{Kepustakaan}

Alan P. Merriam. 1964. The Anthropology of Music. New York: Northwestern University Press.

Banitez, Jesus, A.1977. Barrios Mangore No. 2., Tokyo: Zen-On Music Company Ltd.

Banoe, Pono. 2003. Kamus Musik. Yogyakarta: Kanisius

Basowi \& Suwandi. 2008.Memahami Penelitian Kualitatif. Jakarta: PT. Rineka Cipta.

Fiske, John. 2004.Cultural and Communications Studies. Yogyakarta: Jalasutra

Jamalus.1988. Pengajaran Musik Melalui Pengalaman Musik. Jakarta: Depdikbud Ditjen Dikti, Proyek Pengembangan LPTK.

Nawawi, Handari dan M. Martini Handari. 1992. Instrumen Penelitian Bidang Sosial. Yogyakarta: Gajah Mada University Press.

Prier, Karl-Edmund.1996. IImu Bentuk Musik. Yogyakarta: Pusat Musik Liturgi.
.2011. IImu Bentuk Musik. Yogyakarta: Pusat Musik Liturgi.

Ronald Pen.1992. Introduction to Music. New York: McGraw-Hill, Inc.

Rumengan, Perry. 2009. Musik Vokal Etnik Minahasa Teori, Gramatika, dan Estetika. Jakarta: Panitia Pelaksana Kongres Kebudayaan Minahasa.

Satori, Djam'an dan Aan Komariah. 2011. Metode Penelitian Kualitatif. Bandung: Alfabeta.

Sobur, Alex. 2002. Analisis Teks Media Suatu Analisis Untuk Wacana, Analisis Semiotika Dan Analisis Framing. Bandung: PT. Remaja Rosdakarya.

Stover, Richard. 2012. Six Silver Moonbeams: The Life and Times of Agustin Barrios Mangore. Asuncion, Paraguay: Richard D. Stover

Sugiyono. 2010. Memahami Penelitian Kualitatif. Bandung: Alfabeta

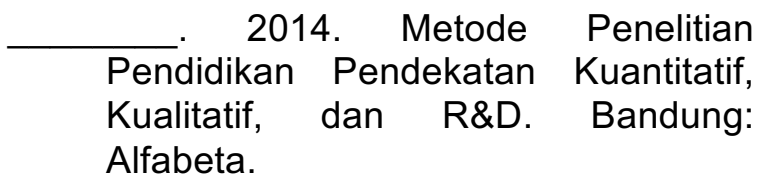

Summerfield, Maurice J.1991. The Classical Guitar: Its Evolution, Players and Personalities since 1800. London: Ashley Mark Publishing. 